\title{
Effect of Different Packaging Materials on Post-Harvest Quality Parameters of Pear under Zero Energy Chamber Storage Condition
}

\author{
Vikram Singh", O.P. Dudi and R.K. Goyal \\ Chaudary Charan Singh Haryana Agricultural University, Hisar-125004, Haryana, India \\ *Corresponding author
}

\begin{tabular}{|c|}
\hline Keywords \\
\hline $\begin{array}{l}\text { Pear, Packaging, } \\
\text { Storage, Zero } \\
\text { energy chambers, } \\
\text { Quality parameters. }\end{array}$ \\
\hline Article Info \\
\hline $\begin{array}{l}\text { Accepted: } \\
\text { 17 July } 2017 \\
\text { Available Online: } \\
\text { 10 September } 2017\end{array}$ \\
\hline
\end{tabular}

\section{Introduction}

Pear fruits, commonly used for table purpose and bearing few small stone cells, are now becoming popular with the consumers for their unique and desirable qualities like fragrance, subtle aroma, appearance, sweetness, crispness and the delicious taste. Pear fruits are good source of sugars, minerals, various bioactive compounds like vitamin $\mathrm{C}$ and natural antioxidants. These chemicals having valuable role in maintaining fruit quality cannot be overlooked.
Some low chilling pear varieties with suitable adaptation to subtropical conditions of northern plains are gaining popularity in India. Such varieties ripen from last week of July to end of August. During these months, due to prevalence of high temperature at harvest, fruits get spoiled rapidly and reduce their shelf life greatly. Short shelf life of pear fruits limits their transportation to far off places whereby a glut like situation created in local markets deprives remunerative prices of 
their produce to the growers, hence warrants a great need to enhance shelf life of pear fruits through simple and suitable means. Fruits stored in zero energy cool chambers get their shelf life enhanced by restricting the respiration and transpiration (Singh et al., 2010).Besides, the storage of fruits in polyethylene films can result in a commodity generated modified atmosphere that diminishes dehydration and preserves freshness (Ben-Yehoshua et al., 1994). Several researchers have investigated the effect of packaging and storage environment on post-harvest storage life and quality of different fruits (Kudachikar et al., 2007).On farm storage plays a vital role in maintaining quality soon after harvest. However, no such systematic work has been done in pear to enhance shelf life by zero energy chamber and different types of packaging materials like modified atmosphere packaging (MAP). Hence, present study was carried out to evaluate the effect of various packaging materials and storage condition on fruit quality of three pear cultivars Patharnakh, Kashmirinakh and Baggugoshaunder zero energy cool chambers.

\section{Materials and Methods}

The experiment was conducted in PostHarvest Laboratory and the ZECC of Department of Horticulture, CCS HAU, Hisar. Fruits of optimum maturity from the similar aged healthy trees of three pear varieties viz., Patharnakh, Kashmirinakh and Baggugosha maintained under uniform cultural practices and harvested with the help of secateurs retaining small intact pedicel, were procured from experimental orchard of College of Agriculture, Kaul (Kaithal), CCS HAU, Hisar. The healthy, uniform sized and disease, injury or bruise free fruits selected for storage were wiped down with muslin cloth to remove dust particles. Two types of packaging material (A) corrugated fiber board (CFB) boxes of two $\mathrm{kg}$ capacity where fruits of all three varieties were packed using newspapers as cushioning material and taken as control treatment, and (B) polyethylene of 0.01 and $0.05 \mathrm{~mm}$ thickness, measured by Lever Type Dial Thickness Guage, United Engineering Corporation, New Delhi, both for the bags of (a) individual fruit packing (IFP) and (b) one $\mathrm{kg}$ fruit packing of all the three varieties was used.

The mouth of polyethylene bags after filling with measured quantity of fruits was tied up. Thereafter half of the packed fruit material was stored at post-harvest laboratory $\left(32 \pm 4^{\circ} \mathrm{C}\right.$ and $\mathrm{RH} 70-75 \%$ ) and remaining half packaged material was kept at zero energy cool chambers $\quad\left(23.2 \pm 3^{\circ} \mathrm{C}\right.$ and $\left.\mathrm{RH} \quad 90-95 \%\right)$ prepared on farm outside of the laboratory. All treatments were replicated four times, taking each box as one replication. Three fruits were taken randomly from $4^{\text {th }}$ replication on every alternate day for analysis of quality parameters. On observations recording dates, i.e. $2^{\text {nd }}, 4^{\text {th }}, 6^{\text {th }}, 8^{\text {th }}$ and $10^{\text {th }}$ day of storage, the mouth of bags was kept open for ten minutes to remove excess gases and moisture sticking the inner side of bags. The TSS of pear fruits with hand refractometer; the acidity and ascorbic as per the method suggested by AOAC (1990) and sugars following the potassium ferricyanide method of Hulme and Narain (1931) was determined.

\section{Results and Discussion}

\section{TSS content (\%)}

Irrespective of packaging treatments, the TSS content of fruits in all the three varieties increased with increasing period of storage (Table 1). The TSS content of $10.2 \%$ recorded in variety Patharnakh at the beginning stage of storage increased progressively reaching maximum of $13.7 \%$ on $10^{\text {th }}$ day of storage. Considering TSS on mean basis, irrespective of storage period, the fruits stored in different types of polyethylene 
showed lower TSS (11.6-12.0\%) as compared to $\mathrm{CFB}$ boxes both at room temperature and zero energy chamber storage condition that had maximum TSS content (12.3\%). Similarly, an increasing trend of TSS was seen from beginning (11.8\%) to the end of storage period $(15.0 \%)$ in Kashmirinakh. Irrespective of storage period, the TSS was recorded minimum in fruits stored in individual fruit packing with PE $0.01 \mathrm{~mm}$ stored at zero energy cool chambers (13.2\%), which was found statistically at par with another polyethylene type. Whereas, the TSS in fruits stored in CFB boxes was found maximum (13.9 and $13.7 \%)$ at room temperature and zero energy chamber storages, respectively. The effect of packaging materials, irrespective of storage, on variety Baggugosha and overall effect on all three varieties was not-significant. At room temperature storage conditions TSS content increased gradually in all the three varieties irrespective of the treatments.

However, on $10^{\text {th }}$ day of storage minimum TSS was recorded in Patharnakh (13.8\%) and maximum in Baggugosha (15.7\%). Similar trend was also observed for zero energy chamber storage. Comparing TSS on overall storage mean basis, irrespective of the varieties and packaging treatments, maximum TSS of $14.8 \%$ was observed on $10^{\text {th }}$ day of storage. Comparing all three varieties irrespective of storage and packaging treatments, the TSS was found minimum in Patharnakh $(11.9 \%)$ while maximum in cv. Baggugosha (14.1\%). Except the storage $x$ variety, the various interactions were not significant. However, among varieties Patharnakh and Baggugosha had minimum TSS content in different types of polyethylene and maximum in CFB boxes stored both at room temperature and zero energy cool chambers. The increasing trend consolidates the previous findings of Nath et al., (2012) and Kaur et al., (2013) in pear. The rise of TSS during storage might be associated with transformation of pectic substances and starch hydrolysis yielding mono and disaccharides and also with dehydration of fruits (Mahajan et al., 2004). Lower TSS content in different polyethylene packaging treatments can be attributed to minimized weight loss, retard ripening and senescence processes which simultaneously slow down conversion of starch into sugars. The pattern of these results resembles with the findings of Rana et al., (2015) in guava. And higher TSS in control treatment of fruits might be associated with more transpirational and respirational losses.

\section{Acidity content (\%)}

The overall mean data for storage indicated that acidity content decreased continuously irrespective of varieties and packaging treatments and minimum $(0.29 \%)$ was recorded on $10^{\text {th }}$ day of storage (Table 2). Based on observations for varieties, irrespective of the storage and packaging treatments, the titerable acidity was found maximum in variety Patharnakh (0.44\%)followed by Baggugosha (0.28\%) and Kashmirinakh (0.26\%).Interactions among variety $\mathrm{x}$ storage and variety $\mathrm{x}$ packaging were found significant, but non-significant among storage $\mathrm{x}$ packaging and storage $\mathrm{x}$ variety $\mathrm{x}$ packaging. However, maximum acidity content was observed on $10^{\text {th }}$ day of storage in fruits of variety Patharnakh stored in PE 0.01 and $0.05 \mathrm{~mm}$ of individual fruit packing at ZEC. Most of polyethylene bags retained higher acidity content of fruits as compared to control, the reason might be the development of modified atmosphere around fruits in PE bags that slowed down various metabolic processes resulting in lower utilization of acids and decreased activity of invertage enzyme resulting in slow conversion of acids into sugars (Wavlah and Athale, 1988). This decrease in acidity can be attributed to conversion of acids into sugars (Sandhu et al., 1989) and utilization of acids during respiration (Waskar et al., 1999). 
Table.1 Effect of packaging materials on TSS $\left({ }^{0}\right.$ brix $)$ during storage of pear at room temperature and zero energy chamber

\begin{tabular}{|c|c|c|c|c|c|c|c|c|c|c|c|c|c|c|c|c|c|c|c|c|c|c|}
\hline \multirow{4}{*}{ Treatments } & \multicolumn{20}{|c|}{ Varieties } & & \multirow{4}{*}{$\begin{array}{l}\text { Grand } \\
\text { Mean }\end{array}$} \\
\hline & \multicolumn{7}{|c|}{ Patharnakh } & \multirow{2}{*}{\multicolumn{6}{|c|}{$\begin{array}{l}\text { Kashmirinakh } \\
\text { Davs after storage }\end{array}$}} & \multirow{3}{*}{$\begin{array}{l}\text { Mea } \\
\text { n }\end{array}$} & \multicolumn{6}{|c|}{ Baggugosha } & \multirow{3}{*}{ Mean } & \\
\hline & \multicolumn{6}{|c|}{ Days after storage } & \multirow{2}{*}{$\begin{array}{l}\text { Mea } \\
\text { n }\end{array}$} & & & & \multicolumn{3}{|c|}{ Days after storage } & & \multicolumn{6}{|c|}{ Days after storage } & & \\
\hline & $\mathbf{0}$ & 2 & 4 & 6 & 8 & 10 & & $\mathbf{0}$ & 2 & 4 & 6 & 8 & 10 & & $\mathbf{0}$ & 2 & 4 & 6 & 8 & 10 & & \\
\hline $\begin{array}{l}\text { CFB boxes } \\
\text { Room (Control) }\end{array}$ & 102 & 109 & 11.7 & 13.1 & 13.8 & 14.2 & 123 & 11.8 & 13.1 & 13.7 & 145 & 149 & 153 & 139 & 125 & 13.6 & 14.3 & 14.9 & 155 & 16.0 & 145 & 135 \\
\hline $\begin{array}{l}\text { CFB } \\
\text { at ZEC }\end{array}$ & 10.2 & 10.8 & 11.5 & 13.0 & 13.6 & 14.1 & 122 & 11.8 & 13.0 & 135 & 14.2 & 14.6 & 15.1 & 13.7 & 125 & 13.4 & 14.1 & 14.8 & 15.2 & 15.8 & 143 & 134 \\
\hline $\begin{array}{l}\text { PE } 0.01 \mathrm{~mm} \text { (IFP) } \\
\text { Room }\end{array}$ & 102 & 10.6 & 11.5 & 12.0 & 133 & 13.9 & 119 & 11.8 & 12.2 & 13.1 & 14.0 & 145 & 14.9 & 134 & 125 & 133 & 14.0 & 14.6 & 15.0 & 15.7 & 14.2 & 132 \\
\hline $\begin{array}{l}\text { PE } 0.01 \mathrm{~mm}(\mathrm{IFP}) \\
\text { ZEC }\end{array}$ & 102 & 105 & 11.4 & 11.8 & 13.0 & 13.7 & 118 & 11.8 & 12.0 & 12.9 & 13.7 & 14.1 & 14.7 & 132 & 125 & 133 & 13.8 & 14.3 & 14.8 & 15.4 & 14.0 & 13.0 \\
\hline $\begin{array}{l}\text { PE } 0.05 \mathrm{~mm} \text { (IFP) } \\
\text { Room }\end{array}$ & 102 & 10.7 & 11.6 & 12.1 & 12.6 & 13.0 & 11.7 & 11.8 & 12.4 & 13.6 & 14.4 & 14.8 & 15.1 & 13.7 & 125 & 13.4 & 14.1 & 14.8 & 155 & 15.8 & 14.4 & 132 \\
\hline $\begin{array}{l}\text { PE } 0.05 \mathrm{~mm} \text { (IFP) } \\
\text { ZEC }\end{array}$ & 102 & 10.6 & 11.5 & 11.9 & 12.4 & 12.9 & 11.6 & 11.8 & 123 & 133 & 14.1 & 14.6 & 15.0 & 135 & 125 & 13.0 & 13.8 & 14.3 & 14.9 & 155 & 14.0 & 13.0 \\
\hline $\begin{array}{l}\text { PE } 0.01 \mathrm{~mm} \\
\text { (1 kg bag) Room }\end{array}$ & 10.2 & 105 & 11.6 & 12.3 & 13.0 & 14.1 & 120 & 11.8 & 125 & 135 & 14.2 & 14.7 & 15.0 & 13.6 & 125 & 12.9 & 14.2 & 14.7 & 14.8 & 15.7 & 14.1 & 132 \\
\hline $\begin{array}{l}\text { PE } 0.01 \mathrm{~mm} \\
(1 \mathrm{~kg} \mathrm{bag}) \text { ZEC }\end{array}$ & 102 & 105 & 11.4 & 12.0 & 12.7 & 13.8 & 118 & 11.8 & 12.4 & 132 & 14.0 & 14.6 & 14.9 & 135 & 125 & 12.9 & 13.9 & 145 & 14.7 & 15.6 & 14.0 & 13.1 \\
\hline $\begin{array}{l}\text { PE } 0.05 \mathrm{~mm} \\
(1 \mathrm{~kg} \mathrm{bag}) \text { Room }\end{array}$ & 102 & 10.6 & 11.5 & 12.4 & 13.1 & 14.0 & 120 & 11.8 & 12.4 & 132 & 13.9 & 14.6 & 15.0 & 135 & 125 & 12.9 & 13.8 & 14.6 & 15.2 & 155 & 14.1 & 132 \\
\hline $\begin{array}{l}\text { PE } 0.05 \mathrm{~mm} \\
(1 \mathrm{~kg} \text { bag) ZEC }\end{array}$ & 102 & 104 & 11.6 & 12.2 & 12.9 & 13.7 & 118 & 11.8 & 12.3 & 13.0 & 13.8 & 14.4 & 14.8 & 134 & 125 & 12.8 & 13.6 & 14.4 & 15.1 & 153 & 14.0 & 13.0 \\
\hline Mean storage & 102 & 10.6 & 115 & 123 & 13.0 & 13.7 & & 118 & 125 & 133 & 14.1 & 146 & 15.0 & & 125 & 132 & 14.0 & 14.6 & 15.1 & 15.6 & & \\
\hline Mean Room & 102 & 10.7 & 11.6 & 12.4 & 13.2 & 13.8 & & 11.8 & 12.5 & 13.4 & 14.2 & 14.7 & 15.1 & & 125 & 13.2 & 14.1 & 14.7 & 15.2 & 15.7 & & \\
\hline Mean ZEC & 10.2 & 10.6 & 11.5 & 12.2 & 12.9 & 13.6 & & 11.8 & 12.4 & 132 & 14.0 & 14.5 & 14.9 & & 125 & 13.1 & 13.8 & 14.5 & 14.9 & 155 & & \\
\hline Storage & 115 & 12.1 & 12.9 & 13.6 & 14.2 & 14.8 & & & & & & & & & & & & & & & & \\
\hline Variety & 11.9 & 135 & 14.1 & & & & & & & & & & & & & & & & & & & \\
\hline \multicolumn{23}{|c|}{\begin{tabular}{l|l}
+2 & \\
\end{tabular}} \\
\hline Storage & 0.18 & & $\mathrm{~S} \times \mathrm{P}$ & & NS & & & CFB & \multicolumn{5}{|c|}{ Corrugated fiber board boxes } & \multicolumn{5}{|c|}{$\mathrm{CD}$ at $5 \%$ for Packaging } & & & & \\
\hline Variety & 0.13 & & $S \times V$ & & 0.31 & & & IFP & \multicolumn{5}{|c|}{ Individual fruit packing } & \multicolumn{2}{|c|}{ Patharnakh } & \multicolumn{2}{|c|}{\begin{tabular}{l|l}
\multicolumn{2}{c}{ ackaging } \\
0.4 \\
4
\end{tabular}} & & & & & \\
\hline Packaging & NS & & $\mathrm{V} \times \mathrm{F}$ & & NS & & & ZEC & Zer & ener & y char & ber & & $\begin{array}{l}\text { Kashn } \\
\text { h }\end{array}$ & ininak & $\begin{array}{l}0.3 \\
7\end{array}$ & & & & & & \\
\hline Room & 0.5 & & $\mathrm{~S} \times \mathrm{V}$ & $\mathrm{xP}$ & NS & & & $\mathrm{PE}$ & Pol & jethyl & & & & Baggu & sosha & NS & & & & & & \\
\hline ZEC & 0.3 & & & & & & & $\begin{array}{l}\text { Roo } \\
\mathrm{m}\end{array}$ & & $n$ ten & perat & & & & & & & & & & & \\
\hline
\end{tabular}


Table.2 Effect of packaging materials on acidity (\%) during storage of pear at room temperature and zero energy chamber

\begin{tabular}{|c|c|c|c|c|c|c|c|c|c|c|c|c|c|c|c|c|c|c|c|c|c|c|c|}
\hline \multirow{4}{*}{$\begin{array}{l}\text { Sr. } \\
\text { No. }\end{array}$} & \multirow{4}{*}{ Treatments } & \multicolumn{21}{|c|}{ Varieties } & \multirow{4}{*}{$\begin{array}{l}\text { Over all } \\
\text { Mean }\end{array}$} \\
\hline & & \multirow{2}{*}{\multicolumn{6}{|c|}{$\begin{array}{c}\text { Patharnakh } \\
\text { Days after storage }\end{array}$}} & \multirow{2}{*}{\multicolumn{7}{|c|}{$\begin{array}{c}\text { Kashmirinakh } \\
\text { Days after storage }\end{array}$}} & \multicolumn{8}{|c|}{ Baggugosha } & \\
\hline & & & & & & & & & & & & & & & \multirow{2}{*}{ Mean } & \multicolumn{6}{|c|}{ Days after storage } & \multirow[t]{2}{*}{ Mean } & \\
\hline & & $\mathbf{0}$ & 2 & 4 & 6 & 8 & 10 & & $\mathbf{0}$ & 2 & 4 & 6 & 8 & 10 & & $\mathbf{0}$ & 2 & 4 & 6 & 8 & 10 & & \\
\hline 1. & $\begin{array}{l}\text { CFB boxes Room } \\
\text { (Control) }\end{array}$ & 0.48 & 0.45 & 0.43 & 0.42 & 0.40 & 038 & 0.43 & 030 & 027 & 0.25 & 0.23 & 022 & 0.20 & 025 & 032 & 028 & 0.25 & 024 & 0.23 & 0.21 & 026 & 031 \\
\hline 2 & CFB ZEC & 0.48 & 0.46 & 0.45 & 0.43 & 0.41 & 039 & 0.44 & 030 & 0.28 & 0.27 & 0.25 & 0.23 & 021 & 026 & 032 & 029 & 0.27 & 026 & 0.24 & 023 & 027 & 032 \\
\hline 3. & $\begin{array}{l}\text { PE } 0.01 \mathrm{~mm} \text { (IFP) } \\
\text { Room }\end{array}$ & 0.48 & 0.47 & 0.46 & 0.44 & 0.43 & 0.42 & 0.45 & 030 & 029 & 0.28 & 0.24 & 0.24 & 0.23 & 0.26 & 032 & 032 & 030 & 027 & 0.26 & 0.25 & 0.29 & 033 \\
\hline 4. & $\begin{array}{l}\text { PE } 0.01 \mathrm{~mm}(\mathrm{IFP}) \\
\text { ZEC }\end{array}$ & 0.48 & 0.48 & 0.47 & 0.45 & 0.44 & 0.43 & 0.46 & 030 & 028 & 0.26 & 0.23 & 0.23 & 0.23 & 0.26 & 032 & 032 & 031 & 028 & 0.27 & 0.26 & 0.29 & 034 \\
\hline 5. & $\begin{array}{l}\text { PE } 0.05 \text { mm (IFP) } \\
\text { Room }\end{array}$ & 0.48 & 0.47 & 0.46 & 0.44 & 0.43 & 039 & 0.45 & 030 & 029 & 0.28 & 025 & 0.25 & 024 & 027 & 032 & 0.28 & 0.25 & 025 & 0.24 & 023 & 0.26 & 033 \\
\hline 6. & $\begin{array}{l}\text { PE } 0.05 \mathrm{~mm} \text { (IFP) } \\
\text { ZEC }\end{array}$ & 0.48 & 0.48 & 0.46 & 0.46 & 0.43 & 0.42 & 0.46 & 030 & 030 & 0.27 & 0.26 & 0.26 & 0.25 & 0.27 & 032 & 030 & 0.27 & 0.26 & 0.26 & 0.24 & 0.28 & 033 \\
\hline 7. & $\begin{array}{l}\text { PE } 0.01 \mathrm{~mm} \\
(1 \mathrm{~kg} \mathrm{bag}) \text { Room }\end{array}$ & 0.48 & 0.46 & 0.44 & 043 & 0.42 & 0.41 & 0.44 & 030 & 0.28 & 028 & 025 & 025 & 023 & 027 & 032 & 031 & 0.28 & 025 & 0.24 & 024 & 027 & 033 \\
\hline 8. & $\begin{array}{l}\text { PE } 0.01 \mathrm{~mm} \\
(1 \mathrm{~kg} \text { bag }) \text { ZEC }\end{array}$ & 0.48 & 0.47 & 0.46 & 0.43 & 0.42 & 0.42 & 0.45 & 030 & 029 & 0.28 & 025 & 025 & 024 & 027 & 032 & 031 & 0.29 & 027 & 0.26 & 0.25 & 0.28 & 033 \\
\hline 9. & $\begin{array}{l}\text { PE } 0.05 \mathrm{~mm} \\
(1 \mathrm{~kg} \text { bag) Room }\end{array}$ & 0.48 & 0.46 & 0.44 & 0.42 & 0.40 & 039 & 0.43 & 030 & 027 & 0.25 & 0.23 & 023 & 022 & 025 & 032 & 030 & 0.28 & 027 & 0.26 & 024 & 0.28 & 032 \\
\hline 10. & $\begin{array}{l}\text { PE } 0.05 \mathrm{~mm} \\
\text { (1kg bag) ZEC }\end{array}$ & 0.48 & 0.46 & 0.45 & 0.43 & 0.40 & 0.40 & 0.44 & 030 & 028 & 0.26 & 024 & 024 & 023 & 026 & 032 & 031 & 0.29 & 028 & 0.28 & 0.26 & 0.29 & 033 \\
\hline \multicolumn{2}{|c|}{ Overall mean for } & 0.48 & 0.47 & 0.45 & 0.43 & 0.42 & 0.40 & & 030 & 028 & 027 & 024 & 024 & 023 & & 032 & 030 & 0.28 & 026 & 025 & 024 & & \\
\hline & Room & 0.48 & 0.46 & 045 & 0.43 & 0.42 & 0.40 & & 030 & 028 & 0.27 & 0.24 & 0.24 & 0.22 & & 032 & 030 & 027 & 026 & 025 & 023 & & \\
\hline & ZEC & 0.48. & 0.47 & 0.46 & 0.44 & 0.42 & 0.41 & & 030 & 029 & 027 & 025 & 0.24 & 0.23 & & 032 & 031 & 029 & 027 & 026 & 025 & & \\
\hline & & & & & & & & & & & & & & & & & & & & & & & \\
\hline & Storage & 037 & 035 & 033 & 032 & 030 & 0.29 & & & & & & & & & & & & & & & & \\
\hline & Variety & 0.44 & 026 & 0.28 & & & & & & & & & & & & & & & & & & & \\
\hline & $\mathrm{CD}$ at $5 \%$ & & & & & & & & & & & & & & $\begin{array}{l}\text { CD a } \\
\text { Packagi }\end{array}$ & $5 \%$ & for & & & & & & \\
\hline & Storage & \multicolumn{2}{|l|}{0.005} & \multicolumn{2}{|c|}{$\mathrm{S} \times \mathrm{P}$} & NS & & & CFB & \multicolumn{5}{|c|}{ Corrugated fibre board boxes } & \multicolumn{2}{|c|}{ Patharnakh } & 0.01 & & & & & & \\
\hline & Variety & \multicolumn{2}{|c|}{0.004} & \multicolumn{2}{|c|}{$\mathrm{S} \times \mathrm{V}$} & \multicolumn{2}{|l|}{0.009} & & IFP & \multicolumn{4}{|c|}{ Individual fruit packing } & & \multicolumn{2}{|c|}{ Kashmirinakh } & 0.01 & & & & & & \\
\hline & Packaging & NS & & $\mathrm{Vx}$ & & 0.01 & & & ZEC & \multicolumn{4}{|c|}{ Zero energy chamber } & & \multicolumn{2}{|c|}{ Baggugosha } & 0.01 & & & & & & \\
\hline & & & & \multicolumn{2}{|c|}{$\mathrm{S} \times \mathrm{V} \times \mathrm{P}$} & NS & & & $\mathrm{PE}$ & \multicolumn{3}{|c|}{ Polyethylene } & & & & & & & & & & & \\
\hline & Room & 0.01 & & & & & & & Room & Room & emper & & & & & & & & & & & & \\
\hline & ZEC & 0.01 & & & & & & & & & & & & & & & & & & & & & \\
\hline
\end{tabular}


Table.3 Effect of packaging materials on ascorbic acid (mg/100 g fruit pulp) during storage of pear at Room temperature and zero energy chamber

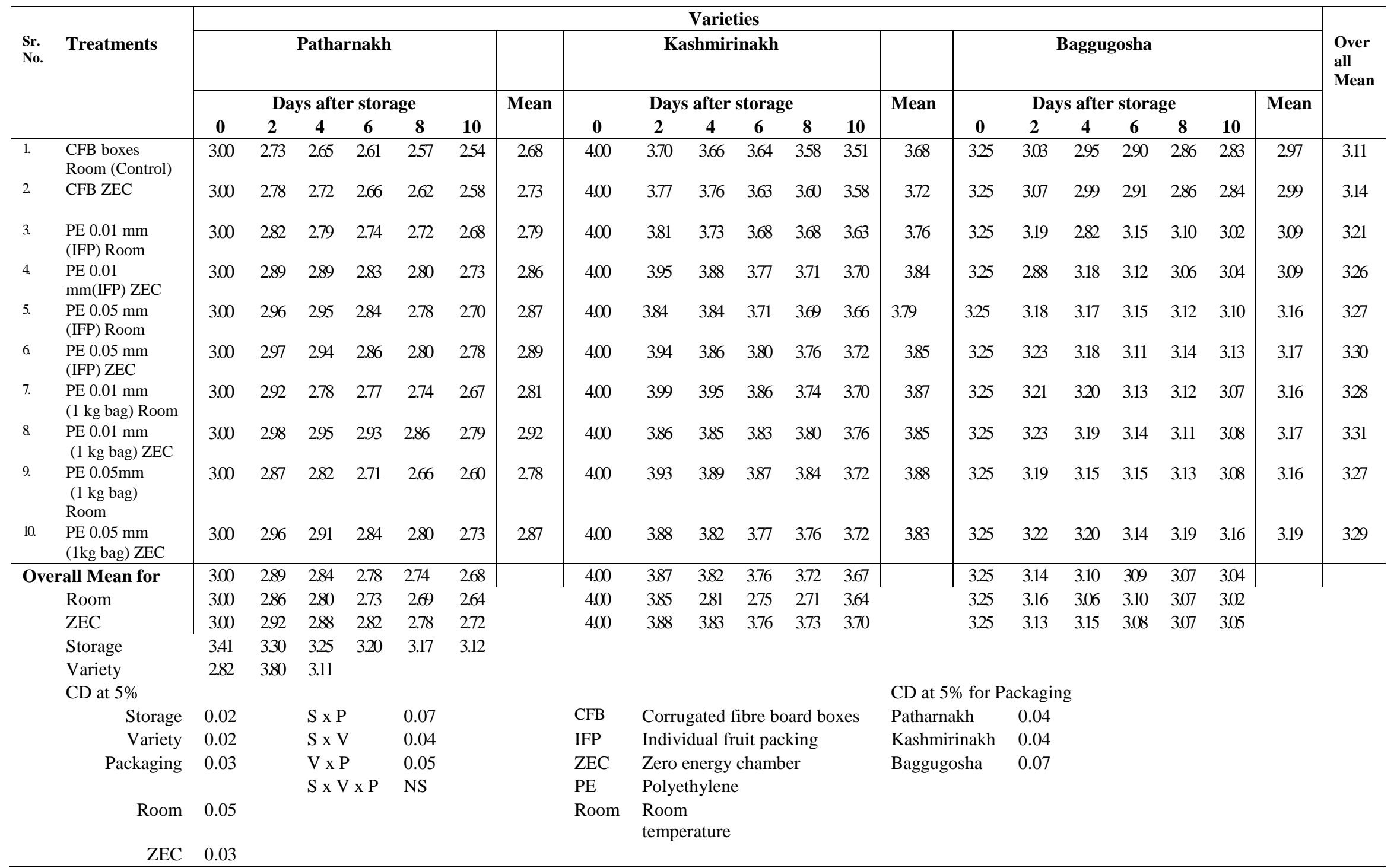


Int.J.Curr.Microbiol.App.Sci (2017) 6(9): 1167-1177

Table.4 Effect of packaging materials on total sugars (\%) during storage of pear at room temperature and zero energy chamber

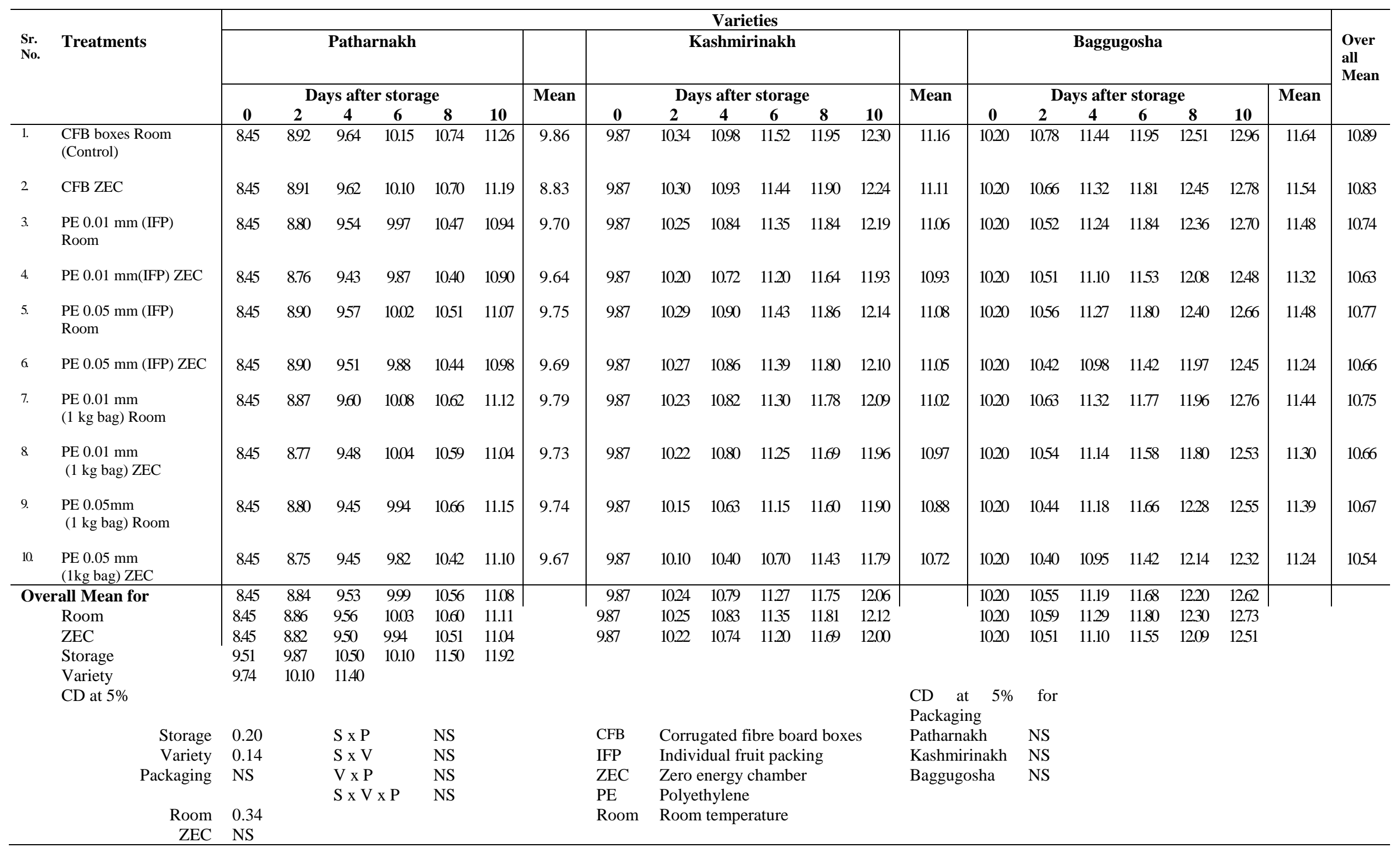




\section{Int.J.Curr.Microbiol.App.Sci (2017) 6(9): 1167-1177}

Table.5 Effect of packaging materials on reducing sugars (\%) during storage of pear at room temperature and zero energy chamber

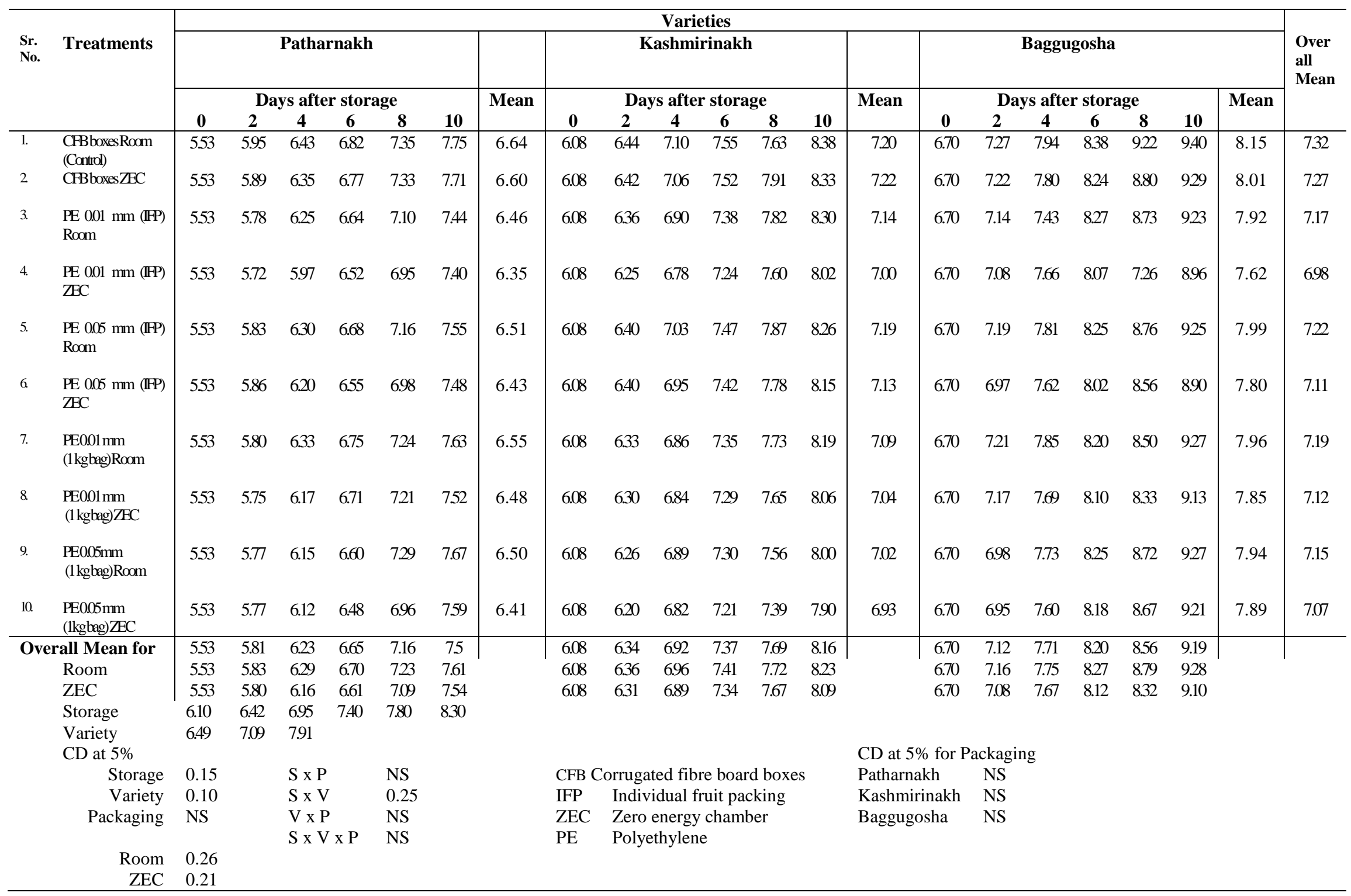


Int.J.Curr.Microbiol.App.Sci (2017) 6(9): 1167-1177

Table.6 Effect of packaging materials on non-reducing sugars (\%) during storage of pear at Room temperature and zero energy chamber

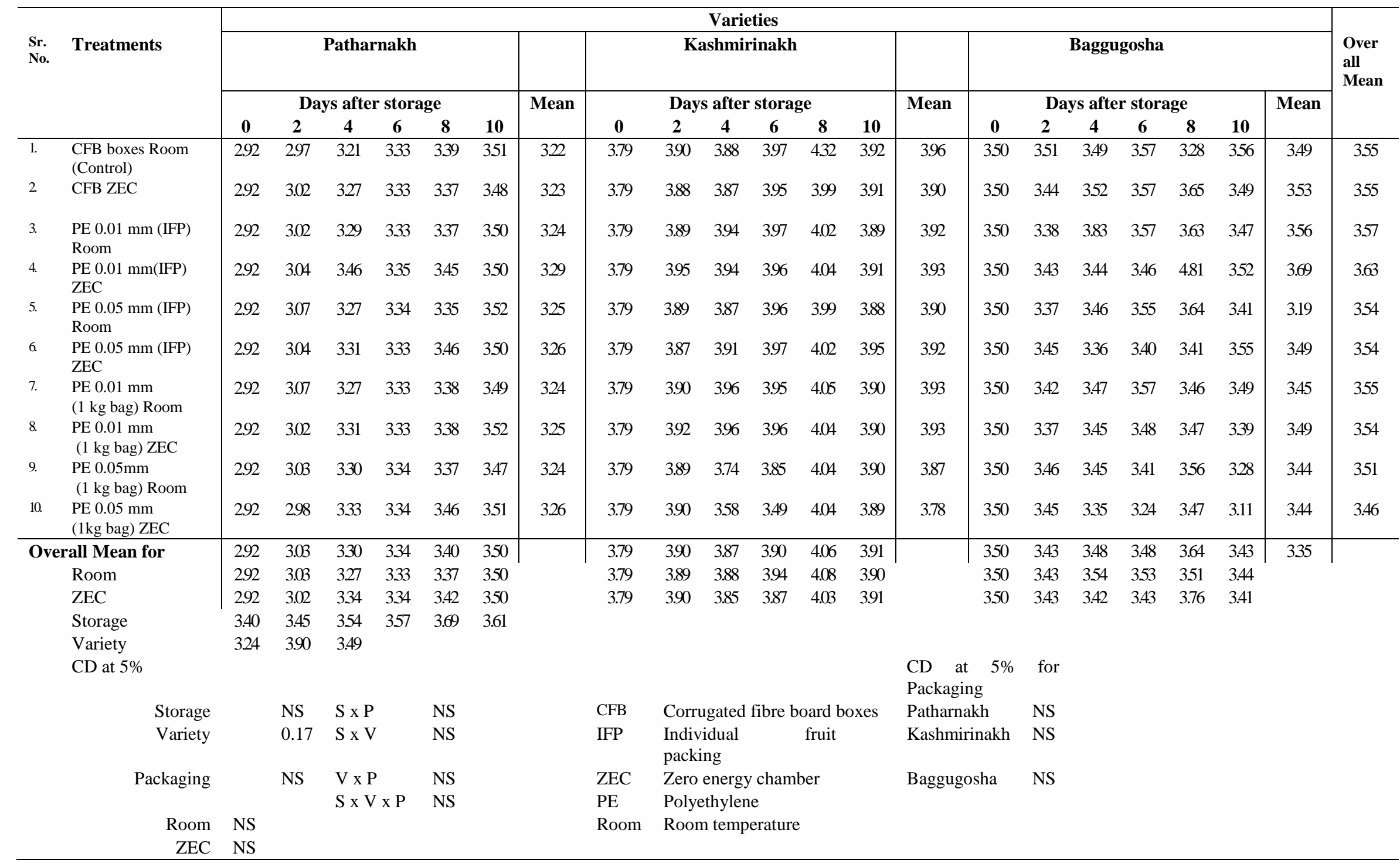


Possibly, the increase in enzyme invertase activity that is responsible for conversion of acids into sugars might have decreased the acidity content of fruits. Nath et al., (2012) also reported a similar decreasing trend in acidity in pear fruits during storage.

\section{Ascorbic acid}

Ascorbic acid content in fruits of all the three pear varieties, irrespective of treatments decreased linearly throughout storage period. Among interactions of storage (S), variety (V) and packaging $(\mathrm{P})$ viz., $\mathrm{S} \times \mathrm{P}, \mathrm{S} \times \mathrm{V}$ and $\mathrm{V} \times \mathrm{P}$ were found significant and second order interaction $\mathrm{S} \times \mathrm{V}$ x $\mathrm{P}$ was not significant (Table 3 ). Hence, maximum retention of ascorbic acid in fruits of all the varieties was found in PE $0.01 \mathrm{~mm}$ of $1 \mathrm{~kg}$ bag stored at ZEC (3.31 $\mathrm{mg} / 100 \mathrm{~g}$ fruit pulp), which was at par with $\mathrm{PE}$ $0.05 \mathrm{~mm}$ of individual fruit packing. However, Kashmirinakh stored in PE $0.05 \mathrm{~mm}$ of $1 \mathrm{~kg}$ bag at room temperature showed maximum ascorbic acid content $(3.88 \mathrm{mg} / 100 \mathrm{~g})$, which was at par with PE $0.05 \mathrm{~mm}$ of IFP at ZEC $(3.85 \mathrm{mg} / 100$ gm) and PE $0.01 \mathrm{~mm}$ of $1 \mathrm{~kg}$ bag both at room temperature and ZEC storage (3.87 and 3.85 $\mathrm{mg} / 100 \mathrm{~g}$ ) while, minimum was in control (3.11 $\mathrm{mg} / 100 \mathrm{~g}$ ). Decrease in ascorbic acid content was observed with advancement in storage period. Similar decreasing trend of ascorbic acid content was reported by Soliva and Martin (2003) in pear. This might be due to enzymatic oxidation of L-ascorbic acid to dehydroascorbic acid during metabolic process causing decrease in ascorbic acid levels in fruits. Polyethylene packed fruits showed higher ascorbic acid content in comparison to control treatment which can be due to slower rate of physiological activities in fruits stored in polyethylene, which resulted in lower physiological loss in weight and loss due to transpiration.

\section{Sugar contents}

The perusal of result in all varieties indicated that sugar content increased continuously with increasing period of storage irrespective of packaging treatments from minimum to maximum (8.45 to $11.08 \%$ ) in Patharnakh; 9.87 to $12.06 \%$ in Kashmirinakh and 10.20 to $12.62 \%$ in Baggugosha on $10^{\text {th }}$ day of storage (Table 4). However, total sugar content of fruits was not affected significantly by packaging treatments in all three varieties. Observation on storage showed total sugars $9.51 \%$ in the beginning to maximum of $11.92 \%$ at the end of storage, whereas, in case of varieties irrespective of storage and packaging treatments, the minimum sugar was recorded in Patharnakh (9.74\%) which was significantly lower as compared to Kashmirinakh (10.10\%) and Baggugosha (11.40\%). The various treatment interactions of storage, variety and packaging were absent. Among various interactions of storage(S), variety (V) and packaging $(\mathrm{P})$ only $\mathrm{S} \times \mathrm{V}$ for reducing sugars was found significant, whereas others effects were not significant (Table 5). Hence on $10^{\text {th }}$ day of storage minimum reducing sugar content was found in variety Patharnakh $(7.57 \%)$ and maximum in Baggugosha (9.19\%).Various interactions of storage (S), variety (V) and packaging (P) were found non-significant. However, in varietal comparisons Patharnakh showed minimum (3.24\%) and Kashmirinakh recorded maximum $(3.90 \%)$ non reducing sugars (Table 6). Increase in sugar content might be attributed to conversion of polysaccharide (starch) into monosaccharide (sugars) and due to hydrolysis of starch into sugars reported by Banday (1996) and Mahajan et al., (2004) in pear. Kumar (2009) also mentioned similar increasing trend up to 21 days and Kaur et al., (2013) up to 60 days in pear. Conversion of starch and complex organic compounds into simple soluble sugar might have lead to the increased level of reducing sugars in pear fruits (Barreiro et al., 1995). Sugar content did not vary significantly in fruits under various storage material treatments. Probably that fruits stored in CFB boxes did not ripe properly but attained total sugars level merely by losing weight through respiration and transpiration processes as seen earlier in comparing PE packed fruits, which showed 
minimum weight loss but attained that level of total sugars during ripening process.

\section{References}

A.O.A.C., 1990.Officaial methods of analysis. Association of Analytical Chemists. $\left(13^{\text {th }}\right.$ Ed.)Washington, D.C.

Banday, F.A., 1996.Cold storage studies in pear cv. 'Le Conte'. Ph.D. Dissertation PAU, Ludhiana.

Barreiro, M.G., Cabral, M.L., Franco J. Gerasopoulos, D. (ed.); Olymplos, Ch (ed.) and Passam, H. 1995. Use of controlled atmosphere storage to extend storage life of 'Rocha' pears. Acta Horticulturae, 379: 537-543.

Ben-Yehoshua, S., Fishman, S., Fang, D.,Rodov, V.(1994). New developments in modified atmosphere packaging and surface coatings for fruits. Proc. Int. Conf. Post -harvest handling of tropical fruits, Chiang Mai, Thailand, 19-23 July 1993, P.250-260.

Hulme, A.C., and Narain, R. 1931. The ferricyanide method for determination of reducing sugars. A modification of Hagedorn Jensen-Hanes Technique. Biochem. J.25:1051-1061.

Kaur, Kirandeep, Dhillon, W.S. and Mahajan, B.V.C. 2013. Effect of different packaging materials and storage intervals on physical and biochemical characteristics of pear. $J$. Food Sci. Technol.50 (1):147-152

Kudachikar, V.B., Kalkarni, S.G., Vasantha, M.S., Aravinda Prasad, B. and Aradhya, S.M. 2007. Effect of modified atmosphere packaging on shelf life and fruit quality of banana stored at low temperature. J. Food Sci. Technol., 44:85-89.

Kumar, Dinesh, 2009. Effect of different polymeric films on the storage life of tray packed pear fruits. M.Sc. Thesis, Punjab Agricultural University, Ludhiana-141004, Punjab, India.

Mahajan, B.V.C., Datt, A.S. and Dhillon, W.S. 2004. Effect of pre storage treatments on the quality and storage life of Asian pear. Indian J. Hort. 61(4):342-344.

Nath, A., Deka C. Bidyut; Singh, Akath; Patel, R.K., Paul D., Misra, L.K. and Ojha, H. 2012. Extension of shelf life of pear fruits using different packaging materials. J. Food Sci. Technol. Oct; 49(5): 556-563.

Rana, Seema, Siddiqui, S. and Goyal, A.2015. Extension of shelf-life of guava by individual packaging with cling and shrink films. J. Food Sci. Technol. 52(12): 81488155.

Sandhu, S.S., Randhawa, J.S. and Dhillon, B.S. 1989.Effect of different forms of calcium, diphenylamine and bavistin on the shelf life of kinnow fruits. Indian J. Hort. 46(3): 327332.

Singh, Sanjay, Singh, A.K., Joshi,H.K., Lata K., Bagle B.G., and More,T.A.(2010).Effect of zero energy cool chamber and post-harvest treatments on shelf-life of fruits under semi-arid environment of western India Part 1, Ber fruits. J. Food Sci. Technol., 47(4): 450-453.

Soliva, F.R.C., Martin, B.O. (2003).Microbial and biochemical changes in minimally processed fresh-cut Conference pears. Eur. Food Res. Technol. 217: 4-9

Waskar, D.P., Nikam, S.K. and Garande, V.K. 1999. Effect of different packaging materials on storage behavior of Sapota under room temperature and cool chamber. Indian J. Agri. Res. 33(4): 240-244.

Wavlah, K.M., and Athale, P.W.1988.Studies to prolong shelf life of mango fruits. Acta Horticulturae, 231: 771-775.

\section{How to cite this article:}

Vikram Singh, O.P. Dudi and Goyal, R.K. 2017. Effect of Different Packaging Materials on PostHarvest Quality Parameters of Pear under Zero Energy Chamber Storage Condition. Int.J.Curr.Microbiol.App.Sci. 6(9): 1167-1177. doi: https://doi.org/10.20546/ijcmas.2017.609.141 